Selcuk Journal of Agriculture and Food Sciences

http://sjafs.selcuk.edu.tr/sjafs/index

Research Article
SJAFS

(2019) 33 (2), 88-93

e-ISSN: $2458-8377$

DOI:10.15316/SJAFS.2019.161

\title{
Estimation of Variance Components for Birth and Weaning Weights in Holstein-Friesian Calves by using WOMBAT software
}

\author{
İbrahim AYTEKIN ${ }^{1 *}$, Şükrü DOĞAN ${ }^{2}$, Ömer ODACI ${ }^{1}$, Göksel GÖKCAN ${ }^{1}$ \\ ${ }^{1}$ Department of Animal Science, Faculty of Agriculture, University of Selcuk, Konya, Turkey \\ ${ }^{2}$ Department of Animal Science, Bahri Dağdaş International Agricultural Research Institute, Konya, Turkey
}

\begin{tabular}{l}
\hline ARTICLE INFO \\
\hline Article history: \\
Received date: 02.05 .2019 \\
Accepted date: 27.05 .2019 \\
\hline Edited by: \\
Osman ÖZBEK; Selçuk University, \\
Turkey \\
Reviewed by: \\
Aşkın GALİÇ; Akdeniz University, \\
Turkey \\
Serdar DURU; UludağUniversity,Turkey \\
\hline
\end{tabular}

\section{Keywords:}

Birth weight

Weaning weight

Heritability

Breeding value

Wombat

Calf

Holstein

\begin{abstract}
The aim of this study was to determine the variance components for birth and weaning weights in Holstein calves. In this purpose, a total of 675 calf birth weight and 295 weaning weight records of Holstein calves raised at Kuzucu Dairy Cattle Farm in Ereğli, Konya Province were used for estimation of phenotypic and genetic parameters for calf birth weight and weaning weight. Phenotypic and genetic parameters were estimated by WOMBAT program using a Single Trait Animal Model (STAM). The model constitutes of additive direct effect, maternal genetic effect (only for Model II) and errors as random effects, birth type, sex of calf, season of birth, year of birth and age of dam as fixed effects. Least square mean of calf birth weight was determined as 34.992 $\pm 0.572 \mathrm{~kg}$. The direct heritability $\left(\mathrm{h}_{\mathrm{a}}{ }^{2}\right)$ of calf birth weight was calculated as $0.180 \pm 0.109$ in Model I and the direct heritability $\left(\mathrm{h}_{\mathrm{a}}{ }^{2}\right)$ and maternal heritability $\left(\mathrm{h}_{\mathrm{m}}{ }^{2}\right)$ of calf birth weight were calculated as $0.154 \pm 0.096$ and $0.141 \pm 0.106$ in Model II, respectively. The effect of calving season, birth type, sex and age of dam on birth weight of calf were significant $(\mathrm{P}<0.01)$, but not calving year $(\mathrm{P}>0.05)$. As for calf weaning weight, least square mean was determined as $74.250 \pm 1.775 \mathrm{~kg}$. For calf weaning weight, the direct heritability $\left(\mathrm{h}_{\mathrm{a}}{ }^{2}\right)$ in Model I was calculated as $0.104 \pm 0.126$ and the direct heritability $\left(\mathrm{h}_{\mathrm{a}}{ }^{2}\right)$ and maternal heritability $\left(\mathrm{h}_{\mathrm{m}}{ }^{2}\right)$ in Model II were calculated as $0.104 \pm 0.127$ and $0.00002 \pm 0.341$, respectively. The effect of calving year $(\mathrm{P}<0.05)$, birth type $(\mathrm{P}<0.05)$, sex $(\mathrm{P}<0.01)$ and birth weight $(\mathrm{P}<0.01)$ on weaning weight of calf were significant, except for calving season and age of dam $(\mathrm{P}>0.05)$ Furtermore, estimated breeding values (EBVs) estimated by BLUP (Best Linear Unbiased Prediction) for calves, sires and dams were found to be in general with the range of -3.245 to $2.577,-2.607$ to 2.631 and -1.714 to 1.747 for birth weight and -2.969 to $2.274,-2.650$ to 2.376 and -1.456 to 1.301 for weaning weight, respectively.
\end{abstract}

\section{Introduction}

Birth weight is one of the most critical traits for livestock. There are significant fluctuations in the weight of a calf over its first week of life. Therefore, it is important to weigh calves as soon as possible. Ideally, birth weight should be measured within 24 hours of birth (Anonymous 2019). In other words, birth weight as the initial criterion of post-natal period is important for growth and development. According to other viewpoint, although birth weight is commonly used as the initial reference point with regard to the development of an individual animal, it represents, in fact, the culmination of the most dynamic growth and develop-

\footnotetext{
* Corresponding author email: aytekin@selcuk.edu.tr
}

ment processes in mammalian biology in prenatal period (Holland and Odde 1992).

Offsprings with higher birth weight have a higher life force and at the same time, they start early yields than others in later periods. Therefore, the correct assessment in the ongoing process depends on the correct measurement of birth weight of calves. Especially, breeders interested in EBVs of birth weight (Estimated Breeding Values) for the sustainability of the farm, should keep records of the birth weights. This practice is extremely important both for calf management and for the sustainability of the farm such as survivability, incidence of diseases, milk and other yields and reproductive performance (Linden et al 2009).

Holland and Odde (1992) stated that calves with lower birth weight may have less vigor, tolerance to cold-stress, resistance to pathological agents, or the ability to overcome parturitional stresses during adap- 
tation to extrauterine life. But, calves that are over weighted at birth may cause varying degrees of dystocia, leading to increased birth asphyxia, metabolic and respiratory acidosis, depressed immunoglobulin absorption, and increased susceptibility to disease. Rahbar et al (2016) stated that extreme birth weights are important for calving ease of the dams and neonatal survival of the calves (Johason and Berger 2003) and increased calf birth weight (CBW) is associated with dystocia, stillbirths, and calf mortality, were all associated with lower calf and cow performance, which can lead to economic losses (Meijering 1984).

Factors affecting birth weight in calves are genetic such as breed and genetic abnormalities and environmental factors such as age of dam, type of birth, dam's size, maternal effect, dam's condition, sex, gestation period, year and season of calving (Kertz et al 1997; Akbulut et al 2001; Bakır et al 2004; Bilgiç \& Alıç 2004; Koçak et al 2007; Koçak et al 2008; Linden et al 2009; Zülkadir et al 2010; Kaygısız et al 2012; Şahin et al 2017).

Genetic selection in dairy cattle is applied to traits that are measured during the animal's productive life, mostly those recorded during early productive life as genetic evaluations are best calculated from unbiased, early data (Coffey et al 2006). The second important criteria after birth weight is the weaning weight. The breeding goal is generally to increase the number of calves weaned per cow per lactation. MacNeil (2005) stated that the phenotypic ratio of a calf's weaning weight to its dam's weight is thought to be an indicator of efficiency of the cow.

To know the effects of environmental factors in evaluating the economically important traits and then standardization according to statistically significant ones is required. Afterwards determination of the selection type according to parameter estimation increases the success in the population. From this perspective, the objective of this study was to investigate the variance components for birth and weaning weights in Holstein calves in a herd.

\section{Materials and Methods}

In this study, a total of 675 birth weight and 295 weaning weight records of Holstein calves raised in intensive conditions at the Kuzucu Dairy Farm in Ereğli, Konya Province, Turkey. Data was recorded between 2017-2019. Analyses were carried out with the records of 675 calves having 31 sires and 587 dams for birth weights, and 295 calves, 22 sires and 282 dams for weaning weights, respectively. Cows were artificially inseminated.

Statistical analyzes were performed in Minitab 16.1.1 with GLM procedure and Tukey comparison test (Minitab, 2010). The effects of calving season, calving year, birth type, sex and age of dam for birth weight, in addition, birth weight as a covariate for weaning weight was included in the analysis by using least squares method. Differences between subgroups of the factors were tested with Tukey test and statistically significant factors were included in the Wombat models.

Genetic analyses were undertaken with Wombat for birth weight and weaning weight of calves. Birth weight trait was handled as covariate in weaning weight. Heritability of these traits were estimated by using Single Trait Animal Model (STAM) of Wombat according to Meyer (2010). Also, the estimated breeding values predicted by BLUP (Best Linear Unbiased Prediction) of Wombat were determinated. The full model in the analysis is included the fixed effects of calving season (from spring to winter), calving year (from 2017 to 2019), birth type (single and twin), sex (male and female), age of dam (from 2 to 6) and the real traits to right of birth weight (BW), birth weight (BW) as a covariate for weaning weight (WW).

Variance components were estimated using the following statistical model.

$$
\begin{array}{ll}
\mathbf{Y}=\mathbf{X b}+\mathbf{Z} \mathbf{u}+\mathbf{e} & (\text { Model I }) \\
\mathbf{Y}=\mathbf{X b}+\mathbf{Z} \mathbf{u}+\mathbf{W} \mathbf{m}+\mathbf{e} \quad(\text { Model II })
\end{array}
$$

where,

$\mathrm{Y}=$ a vector of observation,

$b=a$ vector of fixed effects consisting of calving season, birth type, sex and age of dam for birth weight and fixed effects consisting of calving year, birth type, sex and birth weight as a covariate for weaning weight,

$\mathrm{u}=\mathrm{a}$ vector of animal direct additive genetic effects,

$\mathrm{m}=\mathrm{a}$ vector of random maternal genetic effects,

$\mathrm{e}=\mathrm{a}$ vector of random error.

$\mathrm{X}, \mathrm{Z}$ and $\mathrm{W}=$ incidence matrices relating observations to fixed effects and random effects, respectively.

To estimate direct $\left(\mathrm{h}_{\mathrm{a}}{ }^{2}\right)$ and maternal $\left(\mathrm{h}_{\mathrm{m}}{ }^{2}\right)$ heritabilities, the following equation were used:

$$
\begin{array}{ll}
h_{a}^{2}=\sigma_{a}^{2} /\left(\sigma_{a}^{2}+\sigma_{e}^{2}\right) & \text { (Model I) } \\
h_{a}^{2}=\sigma_{a}^{2} /\left(\sigma_{a}^{2}+\sigma_{m}^{2}+\sigma_{e}^{2}\right) & \text { (Model II) } \\
h_{m}^{2}=\sigma_{m}^{2} /\left(\sigma_{a}^{2}+\sigma_{m}^{2}+\sigma_{e}^{2}\right) & \text { (Model II) }
\end{array}
$$

where;

$\sigma_{a}^{2}=$ additive genetic variance; $\sigma_{m}^{2}=$ maternal genetic variance and $\sigma_{e}^{2}=$ the random residual effect associated with each observation.

\section{Results and Discussion}

The least squares means $(\bar{X})$ and standard errors $\left(S_{\bar{x}}\right)$ and $R^{2}$ values of BW and WW are given in Table 1. 
Aytekin et al. / Selcuk J Agr Food Sci, (2019) 33 (2), 88-93

Table 1

The least squares means $(\bar{X})$ and standard errors $\left(S_{\bar{x}}\right)$ and $R^{2}$ values of BW and WW

\begin{tabular}{|c|c|c|c|c|}
\hline \multirow[t]{2}{*}{ Factors } & $\mathrm{N}$ & $\begin{array}{c}\text { Birth Weight (kg) } \\
\bar{X} \pm S_{\bar{x}}\end{array}$ & $\mathrm{~N}$ & $\begin{array}{c}\text { Weaning Weight (kg) } \\
\bar{X} \pm S_{\bar{x}}\end{array}$ \\
\hline & 675 & $34.992 \pm 0.572$ & 295 & $74.250 \pm 1.775$ \\
\hline \multicolumn{5}{|l|}{ Calving season } \\
\hline Spring & 68 & $36.45 \pm 0.765^{\mathrm{A}}$ & 41 & $74.63 \pm 0.059$ \\
\hline Summer & 78 & $35.94 \pm 0.794^{\mathrm{A}}$ & 19 & $72.81 \pm 2.458$ \\
\hline Autumn & 229 & $33.89 \pm 0.620^{\mathrm{B}}$ & 75 & $74.99 \pm 2.156$ \\
\hline Winter & 300 & $33.69 \pm 0.562^{\mathrm{B}}$ & 160 & $74.57 \pm 1.726$ \\
\hline$P$ & & 0.001 & & 0.790 \\
\hline \multicolumn{5}{|l|}{ Calving year } \\
\hline 2017 & 118 & $34.83 \pm 0.690$ & 118 & $74.59 \pm 1.920^{a b}$ \\
\hline 2018 & 473 & $34.69 \pm 0.531$ & 147 & $76.35 \pm 1.893^{\mathrm{a}}$ \\
\hline 2019 & 84 & $35.45 \pm 0.777$ & 30 & $71.82 \pm 2.183^{b}$ \\
\hline$P$ & & 0.452 & & 0.018 \\
\hline \multicolumn{5}{|l|}{ Birth type } \\
\hline Single & 653 & $39.53 \pm 0.323^{\mathrm{A}}$ & 290 & $77.99 \pm 0.780^{\mathrm{a}}$ \\
\hline Twin & 22 & $30.46 \pm 1.038^{B}$ & 5 & $70.51 \pm 3.418^{b}$ \\
\hline$P$ & & 0.001 & & 0.032 \\
\hline \multicolumn{5}{|l|}{ Sex } \\
\hline Male & 296 & $36.29 \pm 0.598^{A}$ & 125 & $75.75 \pm 1.804^{\mathrm{A}}$ \\
\hline Female & 379 & $33.69 \pm 0.602^{\mathrm{B}}$ & 170 & $72.76 \pm 1.855^{\mathrm{B}}$ \\
\hline$P$ & & 0.001 & & 0.001 \\
\hline \multicolumn{5}{|l|}{ Age of dam } \\
\hline 2 & 305 & $32.92 \pm 0.622^{\mathrm{B}}$ & 139 & $72.59 \pm 1.901$ \\
\hline 3 & 147 & $35.16 \pm 0.647^{\mathrm{A}}$ & 44 & $73.76 \pm 2.077$ \\
\hline 4 & 93 & $35.72 \pm 0.724^{\mathrm{A}}$ & 57 & $75.50 \pm 1.964$ \\
\hline 5 & 78 & $35.87 \pm 0.695^{\mathrm{A}}$ & 32 & $74.88 \pm 1.968$ \\
\hline 6 & 52 & $35.28 \pm 0.861^{\mathrm{A}}$ & 23 & $74.53 \pm 2.363$ \\
\hline$P$ & & 0.001 & & 0.127 \\
\hline BW & & - & & $0.358 \pm 0.0896^{* *}$ \\
\hline 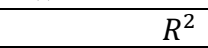 & & 22.72 & & 10.36 \\
\hline
\end{tabular}
cantly $(\mathrm{P}<0.05),{ }^{* * *}: \mathrm{P}<0.01, \mathrm{R}^{2}$ : The coefficient of determination

The least squares means of BW and WW were $34.992 \pm 0.572 \mathrm{~kg}$ and $74.250 \pm 1.775 \mathrm{~kg}$, respectively. In literature, BW was found to be $36.9 \pm 0.29 \mathrm{~kg}$ (Akbulut et al 2001), $36.79 \pm 0.068 \mathrm{~kg}$ (Bilgiç \& Alıç 2004), $38.09 \pm 0.07 \mathrm{~kg}$ (Bakır et al 2004), $38.79 \pm 0.171 \mathrm{~kg}$ (Koçak et al 2007), $38.75 \pm 0.32 \mathrm{~kg}$ (Koçak et al 2008), $42.76 \pm 0.229 \mathrm{~kg}$ (Aksakal \& Bayram 2009), $40.5 \pm 5.8$ $\mathrm{kg}$ (mean \pm SD) (Johanson et al 2011), 38.71 \pm 3.56 and $37.53 \pm 2.09 \mathrm{~kg}$ at two farms (Kaygisiz et al 2012). In general, the values reported in the literature are higher than than the least squares means reported for BW in this study. Also, WW was found to be $65.20 \mathrm{~kg}$ (Bayril \& Y1lmaz 2010) and $79.10 \mathrm{~kg}$ (Hizlı et al 2017). In this study, BW was significantly affected by calving season, birth type, sex and age of dam $(\mathrm{P}<0.01)$. Similar to these findings, some researchers stated that birth weight significantly affected by calving season (Akbulut et al 2001; Bilgiç \& Alıç 2004; Bakır et al 2004; Koçak et al 2007; Aksakal \& Bayram 2009; Kaygisız et al 2012) calving year (Akbulut et al 2001; Bilgiç \&Alıç 2004; Bakır et al 2004; Koçak et al 2007; Koçak et al 2008; Kaygısız et al 2012; Şahin et al 2017), birth type (Bakır et al 2004; Aksakal \& Bayram 2009; Şahin et al 2017), sex (Akbulut et al 2001; Bilgiç \& Alıç 2004; Koçak et al 2007; Koçak et al 2008; Aksakal \& Bayram 2009; Kaygısız et al 2012; Şahin et al 2017) and age of dam (Akbulut et al 2001; Koçak et al 2008; Zülkadir et al 2010; Şahin et al 2017). The effect of calving year $(\mathrm{P}<0.05)$, birth type $(\mathrm{P}<0.05)$, sex $(\mathrm{P}<0.01)$ and $\mathrm{BW}(\mathrm{P}<0.01)$ on $\mathrm{WW}$ has been found to be statistically significant. Similarly, Hizlı et al (2017) stated that effects of calving year and sex on WW found to be statistically significant $(\mathrm{P}<0.01)$. Data structure, mean, standard deviation (SD), coefficient of variance $(\mathrm{CV})$, minimum (MIN) and maximum (MAX) of $\mathrm{BW}$ and WW are given in Table 2. 
Table 2

Data structure, mean, standard deviation (SD), coefficient of variance (CV), minimum (MIN) and maximum (MAX) of BW and WW

\begin{tabular}{lcc}
\hline Traits & Birth Weight $(\mathrm{kg})$ & Weaning Weight $(\mathrm{kg})$ \\
\hline Mean & 37.52 & 78.36 \\
SD & 5.17 & 7.60 \\
CV & 13.78 & 9.70 \\
MIN & 18 & 62 \\
MAX & 52 & 105 \\
\hline No. of records & 675 & 295 \\
No. of valid records & 675 & 295 \\
No. of calf & 675 & 295 \\
No. of sires & 31 & 22 \\
No. of dams & 587 & 282 \\
\hline
\end{tabular}

Mean, standard deviation (SD), coefficient of variation $(\mathrm{CV})$, minimum and maximum values of $\mathrm{BW}$ and WW were found to be as $37.52 \mathrm{~kg}, 5.17,13.78,18 \mathrm{~kg}$, 52 and $78.36 \mathrm{~kg}, 7.60,9.70,62 \mathrm{~kg}, 105 \mathrm{~kg}$, respecti-

Table 3

Estimates of variance components, heritabilities $\left(\mathrm{h}^{2}\right)$ for BW and WW

\begin{tabular}{|c|c|c|c|c|c|}
\hline \multirow{2}{*}{ Estimations } & \multirow{2}{*}{$\begin{array}{l}\text { Traits } \\
\text { Model }\end{array}$} & \multicolumn{2}{|c|}{ Birth Weight } & \multicolumn{2}{|c|}{ Weaning Weight } \\
\hline & & I & II & I & II \\
\hline$\overline{\sigma_{a}^{2}}$ & & 3.78267 & 3.22677 & 5.52878 & 5.52874 \\
\hline$\sigma_{m}^{2}$ & & - & 2.95247 & - & 0.00100 \\
\hline$\sigma_{\mathrm{e}}^{2 \mathrm{~m}}$ & & 17.2166 & 14.7725 & 47.5094 & 47.5086 \\
\hline$\sigma_{p}^{2}$ & & 20.9993 & 20.9517 & 53.0382 & 53.0383 \\
\hline$h_{a}^{2}$ & & $0.180 \pm 0.109$ & $0.154 \pm 0.096$ & $0.104 \pm 0.126$ & $0.104 \pm 0.127$ \\
\hline $\mathrm{h}_{\mathrm{m}}{ }^{2}$ & & $\begin{array}{c}0.100+010 \\
-\end{array}$ & $0.141 \pm 0.106$ & - & $0.00002 \pm 0.341$ \\
\hline Maximum $\log \mathrm{L}$ & & -1358.986 & -1358.180 & -730.955 & -730.955 \\
\hline AIC & & -1358.986 & -1361.180 & -732.955 & -733.955 \\
\hline AICC & & -1360.995 & -1361.198 & -732.975 & -733.996 \\
\hline BIC & & -1365.486 & -1367.930 & -736.621 & -739.454 \\
\hline Penalty factor & & 3.250 & 3.250 & 2.833 & 2.833 \\
\hline
\end{tabular}

$\sigma_{\mathrm{a}}^{2}=$ direct additive genetic variance; $\sigma_{\mathrm{m}}^{2}=$ maternal genetic variance, $\sigma_{\mathrm{e}}^{2}=$ temporary environmental variance, $\sigma_{\mathrm{p}}^{2}=$ phenotypic variance, $\mathrm{h}_{\mathrm{a}}{ }^{2}=$ direct heritability, $\mathrm{h}_{\mathrm{m}}^{2}=$ maternal heritability, $-2 \log \mathrm{L}=\log$ likelihood, AIC \& AICC and BIC: Akaike and Bayesian information criterions

Estimated variance components for calf weight at birth and weaning were given in Table 3 calculated according to two models; Model I: direct additive genetic effects and Model II: direct and maternal genetic effects. As a result of Model I for BW, direct additive genetic variance and phenotypic variance were found to be as 3.783 and 20.999, respectively, and direct heritability $\left(\mathrm{h}_{\mathrm{a}}^{2}\right)$ was calculated as $0.180 \pm 0.109$. As for Model II for BW, direct additive genetic variance, maternal genetic variance and phenotypic variance were found to be as $3.227,2.953$ and 20.952, respectively, so direct $\left(\mathrm{h}_{\mathrm{a}}{ }^{2}\right)$ and maternal $\left(\mathrm{h}_{\mathrm{m}}{ }^{2}\right)$ heritabilities were calculated as $0.154 \pm 0.096$ and $0.141 \pm 0.106$, respectively. In the same way, considering variance components, direct heritability $\left(\mathrm{h}_{\mathrm{a}}{ }^{2}\right)$ was calculated as $104 \pm$ 0.126 in Model I and direct $\left(\mathrm{h}_{\mathrm{a}}{ }^{2}\right)$ and maternal $\left(\mathrm{h}_{\mathrm{m}}{ }^{2}\right)$ heritabilities were calculated as $0.104 \pm 0.127$ and $0.00002 \pm 0.341$, respectively, for WW. When the information criteria were examined, it was found that the information criteria in the models within both traits had similar results.

In literature, Akbulut et al (2001) reported that heritability estimation belonging BW was found as $0.24 \pm$ 0.177 for Holstein Friesian. Bilgiç \& Alıç (2004) esti- vely. As a result of analysis by using Wombat program, estimates of variance components, heritabilities $\left(\mathrm{h}^{2}\right)$ according to two models for BW and WW are given in Table 3 . 
Johanson et al (2011). In Tahirova and Polatlı Holstein dairy farms, direct heritability estimations was found to be 0.15 and 0.04 , while, maternal heritability estimations for the same traits are 0.56 and 0.002 , respectively, (Kaygısız et al 2012). Şahin et al (2017) estimated direct heritability as $0.11 \pm 0.015$ in Model 1 , direct heritability as $0.10 \pm 0.025$ and maternal heritability $0.09 \pm 0.039$ in Model 4 for BW of Holstein calves in Tahirova dairy farm. Briefly, direct heritabilities of the BW was found to be in general with the range of 0.04 to 0.53 , maternal heritabilities with the range of 0.002

Table 4

Maximum and minimum breeding values (BVs) with standard errors and accuracies of calves, sires and dams for BW and WW

\begin{tabular}{|c|c|c|c|c|c|c|}
\hline & \multicolumn{3}{|c|}{ Birth Weight } & \multicolumn{3}{|c|}{ Weaning Weight } \\
\hline & CBVs & SBVs & DBVs & CBVs & SBVs & DBVs \\
\hline Minumum & $-3.245 \pm 1.614$ & $-2.607 \pm 0.907$ & $-1.714 \pm 1.899$ & $-2.969 \pm 1.514$ & $-2.650 \pm 0.880$ & $-1.456 \pm 1.761$ \\
\hline Maximum & $2.577 \pm 1.716$ & $2.631 \pm 1.589$ & $1.747 \pm 1.857$ & $2.274 \pm 1.613$ & $2.376 \pm 1.507$ & $1.301 \pm 1.736$ \\
\hline $\begin{array}{l}\text { Percentage of animal } \\
\text { over the mean EBVs }\end{array}$ & 43.41 & 48.39 & 50.60 & 42.81 & 54.84 & 50.77 \\
\hline Accuracy (\%) & 41.8 to 56.6 & 20.9 to 88.5 & 20.8 to 35.2 & 38.7 to 53.9 & 19.3 to 87.2 & 19.1 to 29.1 \\
\hline $\operatorname{Accuracy}(\bar{X})$ & 52.54 & 52.00 & 22.59 & 59.94 & 49.64 & 20.58 \\
\hline
\end{tabular}

When the Table 4 was evaluated, if it was possible, it was stated that success in selection and culling of animals for the next generation can be achieved by choosing animals with EBVs over the mean. It is also necessary to pay attention to accuracy of breeding values (BV) from calves, sires and dams for BW and WW. If there is a problem in regard to vitality because of low BW, a selection can be done towards high breeding value in order to increase of vitality in a herd or population. However, it is important to consider the both accuracy of breeding values and animals breeding values in this selection process. Thus, selection for the next generation would lead to higher genetic improvement in the herd or population.

Since calves are feed with milk in rearing system from birth to weaning, it can be said that the decrease of $\mathrm{h}^{2}$ for WW may be due to maternal effect was not large influence for WW rather than BW. An alternative explanation for the low heritabilities of these traits might be due to luck of a proper mating program. According to these results, it can be expressed that family selection should be preferred to increase both BW and WW for this herd.

In recent years, dairy cattle breeders have shown an increasing interest in selection for economically important traits such as easy parturition and calf viability, which are not classical production traits. Since genetic selection could improve calving performance, it is important to include calving traits in genetic evaluations, although their implementation is not straightforward (Eaglen et al 2012). BW is also a critical quantitative trait that effects many economically traits. Hereby, BW is a sign of the calves' future development and growth rate, as well as an indicator of the calving to 0.56 in literature, and the findings in this study were similar with most of them. As for WW, direct heritabilities were found to be 0.13 (At1l 2005), 0.29 (Khattab et al 2009) and 0.79 (Coffey et al 2006), and maternal heritability was found to be 0.09 (Khattab et al 2009). The findings of this study about WW in this study were similar to the values reported by Atıl (2005) and lower than Coffey et al (2006) and Khattab et al (2009) findings. The estimated breeding values (EBVs) are presented in Table 4, which were predicted in WOMBAT with BLUP. ease. In this respect, it is one of the most fundamental herd management traits that should be focused on.

\section{Acknowledgements}

This research was a grant, supported by The Scientific Research Projects Office of Selcuk University, Turkey. We are thankful to Kuzucu Dairy Farm for support to this scientific study.

\section{References}

Akbulut Ö, Bayram B, Yanar M (2001). Estimates of Phenotypic and Genetic Parameters on Birth Weight of Brown Swiss and HolsteinFriesian Calves Raised in Semi Entansif Conditions. Journal of Lalahan Livestock Research Institute, 41(2), 1120.

Aksakal V, Bayram B (2009). Estimates of genetic and phenotypic parameters for the birth weight of calves of Holstein Friesian cattle reared organically. Journal of Animal and Veterinary Advances, 8(3), 568-572.

Anonymous (2019). Understanding Birth Weight EBVs.

http://breedplan.une.edu.au/tips/Understanding\%20 Birth\%20Wt\%20EBVs.pdf. Access Date: [29.04.2019]

Atıl H, Khattab AS, Badawy L (2005). Genetic parameter of birth and weaning weights for Friesian calves by using an animal model. Archives Animal Breeding, 48(3), 261-269.

Bakır G, Kaygısız A, Ulker H (2004). Estimates of genetic and phenotypic parameters for birth weight 
in Holstein Friesian cattle. Pakistan Journal of Biological Sciences, 7(7), 1221-1224.

Bayril T, Y1lmaz O (2010). Growth Performance and Survival Rate Traits in Holstein Calves Raised inKazova Vasfi Diren Agriculture Farm. Yüzüncü Yll Üniversitesi Veteriner Fakültesi Dergisi, 21(3), 163-167.

Bilgiç N, Alıç D (2004). Genetic and Phenotypic Parameter Estimates of Birth Weight in Holstein Friesian Calves. Ankara University Journal of Agricultural Sciences, 10(1), 72-75.

Coffey MP, Hickey J, Brotherstone S (2006). Genetic aspects of growth of Holstein-Friesian dairy cows from birth to maturity. Journal of Dairy Science, 89(1), 322-329.

Eaglen SA, Coffey MP, Woolliams JA, Wall E (2012). Evaluating alternate models to estimate genetic parameters of calving traits in United Kingdom Holstein-Friesian dairy cattle. Genetics Selection Evolution, 44(1), 23.

Hızlı H, Ayaşan T, Asarkaya A, Coşkun MA, Yazgan E (2017). Growth Performance and Survival Rate Traits in Holstein CalvesRaised in East Mediterrenean Agricultural Research Institute Farm. Iğdir Journal of the Institue of Science and Technology, 7(1), 383-389.

Holland MD, Odde KG (1992). Factors affecting calf birth weight: a review. Theriogenology, 38(5), 769798.

Johanson JM, Berger PJ, Tsuruta S, Misztal I (2011). A Bayesian threshold-linear model evaluation of perinatal mortality, dystocia, birth weight, and gestation length in a Holstein herd. Journal of Dairy Science, 94(1), 450-460.

Kaygısız A, Bakır G, Yılmaz I (2012). Genetic parameters for direct and maternal effects and an estimation of breeding values for birth weight of Holstein Friesian calves. Bulgarian Journal of Agricultural Science, 18(1), 117-124.

Kertz AF, Reutzel LF, Barton BA, Ely RL (1997). Body weight, body condition score, and wither height of prepartum Holstein cows and birth weight and sex of calves by parity: A database and summary. Journal of Dairy Science, 80(3), 525529.
Khattab AS, Omer AE, Emam AI (2009). Estimation of direct and maternal genetic effects for body weight at different ages for Holstein-Friesian calves in Egypt. Állattenyésztés és Takarmányozás, 58(4), 305-314.

Koçak S, Tekerli M, Özbeyaz C, YüceerB (2007). Environmental and genetic effects on birth weight and survival rate in Holstein calves. Turkish Journal of Veterinary and Animal Sciences, 31(4), 241-246.

Koçak S, Tekerli M, Özbeyaz C, Demirhan İ (2008).Some Production Traits of Holstein, BrownSwiss and Simmental Cattle Reared in LalahanLivestock Research Institute. Journal of Lalahan Livestock Research Institute, 48(2), 51-57.

Linden TC, Bicalho RC, Nydam DV (2009). Calf birth weight and its association with calf and cow survivability, disease incidence, reproductive performance, and milk production. Journal of Dairy Science, 92(6), 2580-2588.

MacNeil MD (2005). Genetic evaluation of the ratio of calf weaning weight to cow weight. Journal of Animal Science, 83(4), 794-802.

Meyer K (2010). WOMBAT: A program for mixed model analyses by restricted maximum likelihood. Retrieved from http://didgeridoo.une.edu.au/km/homepage.php.

Minitab (2010). Minitab 16.1.1 for Windows. State College, PA, USA: Minitab Inc.

Rahbar R, Abdullahpour R,Sadeghi-Sefidmazgi A (2016). Effect of calf birth weight on milk production of Holstein dairy cattle in desert climate. JABB-Online Submission System, 4(3), 65-70.

Şahin A, Ulutaş Z, Uğurlutepe E (2017). The application of six different models to estimate the genetic parameters, variance components and breeding values for birth weight of Holstein calves. Journal of Applied Animal Research, 45(1), 598602.

Zülkadir U, Keskin İ, Aytekin İ, Khattab AS(2010). Estimation of Phenotypic and Genetic Parameters and Effectof Some Factors on Birth Weight in Brown Swiss Calves in Turkey Using MTDFREML. 2nd International Symposium on Sustainable Development. 8-9 June 2010,Sarajevo. 